\title{
The Effect of Commerce and Trade in the Development of Great Khorasan during the Early Centuries after the Arrival of Islam
}

\author{
Mansoureh SAHEBIBAZAZ ${ }^{1, *}$, Ahmad TONDI $^{2}$ \\ ${ }^{1}$ Department of history, Tajik international university, Dushanbe, Tajikistan. \\ ${ }^{2}$ Department of Crafts, Art university of Tehran, Tehran, Iran. \\ *Corresponding author: Sahebi_46@yahoo.com
}

\begin{abstract}
Trade can be one of the most influential factors in the development of cities, as in the Great Khorasan region during the centuries after the arrival of Islam. After consolidation of the Islamic regime in Iran including Great Khorasan, the society changed because of the teachings of Islam, thinking about social classes and productive works. Hence, the ground for generating jobs in urban areas emerged. Most produced goods in this period were based on agriculture and livestock products. These products were produced on a large scale and variety. Thus, the export of surplus goods to other areas was pursued by people and governments. The primary export destinations were markets of cities. Because of the geographical location of Khorasan region, most cities were along the routes through which Muslims could establish trade relations and economic transactions with other nations, export their goods and import the needed materials. Hence, the cities which were located on the trade routes would attract a great population due to their economic attractions and wealth creation leading to the expansion and development of cities in the region.
\end{abstract}

Keywords: Great Khorasan, urban development, economy and commerce, the Islamic period.

\section{Introduction}

One of the important topics in the urban history studies is to examine the effect of economic and business development in regional scale. "The early centuries of Islam arrival in Iran" is one of the historical periods that have valid written documentary sources. During this period, despite that Iran had embraced the religion of Islam, but due to its long history of urbanization showcased a different picture in the creation of urban culture. The great land of Khorasan is one of the areas that has special characteristics because of the vastness of the land and distance from the center of government (Baghdad), historical events, the type of land administration, urban development and other reasons, which independently are valuable for thorough studies. For this reason, the aim of this paper is to examine the role of business in the third to seventh century AD, in the cities of Great Khorasan.

From the late third century, rulers with Iranian origin seized political power. Hence, the creation of various cultural manifestations such as urban development was remarkable. Because the cultural and artistic characteristics of pre-Islamic era in Iran were combined with Islamic thought and beliefs, it resulted in a visual fusion of dramatic developments in all aspects of Islamic culture in Iran [1].

Most cities in Khorasan, who had a social life at this time had grew out of old cities and major changes in old tissues. The growth of these cities was affected by different factors that their 
level of significance varied. The largest and most influential factor of growth in major cities of Khorasan during the third to the seventh centuries was trading. In this period, due to the dominance of socio-cultural teachings of Islam over the course of public life, slowly vast changes in values appeared such as on labor relations, process of production and economic life of people. The result of such a process was setting aside social-mental barriers that had slowed done the work force population growth and expansion of production fields and good jobs.

Changes resulting from increasing productive jobs in towns and villages manifested in formation of different neighborhoods and gave importance to finding the social space in urban life.

As a result of these changes, the social atmosphere in Iran before Islam that was based on the differentiating between people in terms of their socio-political situation and "spatial segregation" changed and moved towards the theoretical model based on criteria of social egalitarianism and equality. By following this process, the Sassanid city slowly obtained the theoretical and practical requirements for proper growth in the Islamic period [2]. Also, because of manufacturers' need to present their surplus goods in the market as the main exchange center in each city as well as export to outside the region, the necessity of planning for these issues was felt.

Thus, policy, planning and forecasting to trade agricultural products and industrial artifacts with outside of Khorasan became a priority. The emergence of caravanserais on the ways, improving roads health and safety, protecting the safety of cities along the way are among the programs that the governments performed. Taken together, these measures could result in trade prosperity and wealth of cities. Rich cities would increase civility, thereby attracting more people into cities leading to their development and reclamation.

\subsection{The role of regional and trans-regional trade in growth of cities in the Great Khorasan:}

Khorasan region has been distinguished from pre-Islamic times due to its proximity to mainland of China and India, the estuary of India, which is known as the Gateway to China [3], Hence, trade had a long history in this area. In the first two centuries after the conquest of Islam in Iran and the lack of stability throughout the territory of Iran including Great Khorasan, all of the urban growth factors began to wane, and many cities were destroyed by the attacks of the Arabs. Bukhara and Beikand [4] are two instances. But by establishing an Islamic state, gradually the ground of development and growth of cities was provided so that even cities that had been destroyed at the beginning of Islam were rebuilt again. In such a way that the speed of development and wealth increased in this period compared to the pre-Islamic period in Khorasan region. It is appropriate to examine the causes of these changes.

Increase of productive jobs in cities and villages: accepting the teachings of Islam by the people in Iran, including Great Khorasan lead to changes in the underlying beliefs and values of people. The former beliefs included instructions that confirmed the inequality and difference among community members. This issue was irrefutably institutionalized in the Sassanid period. The result of this change was that the urban community that was based on difference and segregation of public based on their social status and did not allow the people to choose their place of residence and lifestyle moved toward a model that was theoretically 
based on criteria of social egalitarianism and equality. By following this thought, Sassanid city slowly achieved the theoretical and practical requirements for proper development of Islamic thought and doctrine. Thus, the doctrine of equality of individuals became a dominant belief. Finally, this belief contributed to reinforcement and boost of many productive fields such as agriculture and industries. Moreover, the increasing production provided the ground for migration to cities. The early fruit of residence of people in the cities was formation of different neighborhoods that were named after the name of each caste. This shows the respect of Islam religion to productive jobs.

Detailed description of materials produced and their diversity can be followed in each of the cities of Khorasan. For example, the canvas and silk clothes of Nishapur, the tanned goat skin of Guzganan, the camel of Sarakhs, the burlap and sackcloth in Qaen [3] are some of these products. Balkh productions included bergamot, orange, sugar cane, lotus, camel, as well as sesame, rice, Doushab, almonds, walnuts, pomegranates and grapes [5], the fragrance and soap of Balkh were its other popular export products [6]. There were many other goods produced such as cedar wood in Poushang [3]; and camel, raw silk, silk yarn, silk clothing, scarves, fabrics, high quality cotton, pudding, salt and vinegar, as well as long-lasting melon, sesame oil, different perfumes, copper pots and manna in Marv [3]. Productions of Sughd province and Samarkand included slave [7], Samarkand burlap, copper pots and a variety of equipment for horseback riding. But the most desirable export of Samarkand was high quality paper that could compete with Chinese paper. Among Bukhara products a fabric called "Zandiji" which was woven in Zandaneh and many cities of Bukhara was famous. The fabric was so skillfully woven that after being sent to Iraq and Persia its value shall equal Diba (silk) $[3,4]$ cotton garments known as Bekhari, carpets, wool coats and prayer rug [8] beautiful silk, linen and wool fabrics [4] also, soft fabrics, prayer rug, carpet, wool for bed, belts for horses, Eshmuni clothes, tallow, deer leather and Grease were the other products of Bukhara city [6]. In addition to providing job opportunities for local people, these products brought about the sale of surplus production and extraction of wealth, and expansion of cities.

\subsubsection{Establishment of permanent trade centers (markets):}

The growth of productive jobs increased the need to settle a permanent location for manufactured goods. In these places (market) manufacturers could provide manufacturers a place to trade in the region, as well as trans-regional.

The background of emerging permanent markets should be the seasonal markets. The markets were held in determined places and times, usually on the ways toward the towns, villages, etc. Holding markets on a regular basis led to the emergence of villages. After this stage, the population in the vicinity of permanent and temporary markets caused a rapid urban growth. Instances can be urban development of Balkh [5], Marv, Herat [3], as well as the cities inside and around Bukhara fence. [8] In Sharagh (one of the villages of Bukhara) a market was held for ten days in the middle of winter that sheepskin and wood timbres constituted the major commodities. In another town in Bukhara named Darakhsheh, a market was formed once every fifteen days [4]. Also, Tavaveis market in one of the towns of Bukhara was a seasonal market where the secondhand and outdated goods were sold [8]. This has led to the development of these cities. 


\subsubsection{The cities' suburb (Rabz) as the central point of economic gravity:}

During the early centuries after the advent of Islam, in cities of Khorasan, the city center transferred from "citadel" to the outside (Suburbs) of cities. This change led to growth and development of commercial and residential neighborhoods in cities, because increased productivity and trade caused the growth of urban population, especially the neighborhoods where professionals and craftsmen lived.

With the expansion of suburbs, state officials were also settled in this area, meanwhile the mosque as the most important social and religious organization of city was gradually located in the suburbs. This increased the importance of city suburbs and they became the gravity point in Khorasan before 7th century AD. [8, 9]. The neighborhoods in some of Greater Khorasan's cities can be identified in historical documents. Moqadasi says "Nishapur has forty-two neighborhoods that some of them are half the size of Shiraz. Its spacious streets that lead to the city gates are not less than fifty and the Jameh Mosque is in the suburbs" [6]. Narshakhi has pointed to a number of neighborhoods including farmers' neighborhood, the neighborhood of Arabs, Moghan koi, Gardon keshan koi, Rendan neighborhood, Minister Ibn Ayub Hassan neighborhood, Ala neighborhood, Darvazjeh neighborhood, Faghsadareh neighborhood, etc. in Sharestan of Bukhara [4] in the suburbs of the city, he notes the ministers and bureaucrats's palaces, Amir Nasr Samani Palace, Abujafar Atbi Mosque, Fazl Barmaki Moasqe, etc. [4]. The reasons for the gathering of a group of people in a neighborhood were different. Some of these factors include: similar jobs, same religious and ritual beliefs, same city of origin.

\subsubsection{The cities' location on trade roads:}

One of the characteristics of Great Khrasan region that provided the economic prosperity of the whole region and thus growth of population and urban development, was its location in East-West trade routes. There was the China road to Iran in the east of Khorasan, the Turks and Russia's land, Khazarm and Caucasus from north, Byzantium from the west and North Europe. These cities have always been the center of trade of goods that were transacted along the trade routes from East to West. In Abbasid caliphate, the area ruled by Muslims reached its greatest extent, the most famous commercial road was the road to the Great Khorasan toward northeast and through this road Baqdad connected to the cities of Transoxiana near China. The road route largely corresponds to the way that later became known as the Silk Road. It began from Khorasan's gate in eastern Baghdad and after passing through the Zagros Mountains of Iran continued through the desert of Ghomes. The Tabarestan Mountains on the left side and the salt desert on the right, this road entered to the province of Khorasan near Bastam, passed through Nishapur and Tus to Marv. It continued with Karakum desert and came to the banks of the River Oxus about Amol. After leaving Bukhara and Samarkand behind, it arrived Zamin in the East of Samarkand. The road divides here to two branches: the left head toward Chach, from there to OAtrar on the beach of Low Oxus. The other way deviated from zamin to the right, and to the Upper Oxus and Farghana state, after passing through the area, it arrived Ozkand desert on the border with China [10].In the Islamic centuries, the city of Balkh was almost the farthest limit of China road to the West [11]. The 
cities which were located on the side of the road attracted people due to favorable economic conditions. By the increasing population development and urbanization also came.

The traffic in the roads between cities caused the cities to change to fit with prevalent business activities. Building caravanserais and roadhouses outside the towns and cities, and Caesarea and Timcheh in the markets are among these changes by which a great profit was earned from one hand and lead to overpopulation and urban development on the other hand. "... And I have heard that there are extra than ten thousand caravansaries in Mesopotamia, which, whomever arrives will find food and grass for the quadruped" [3]. Like the city Beikand near Bukhara which has had more than a thousand caravansaries so that each of the cities had made one there to deal with China. In each of these stations armed groups resided to fight against the thief Turks [3].

Another feature of cities developed due to business expansion was that they become politically important. Because of its location on the commercial roads, the city of Samarkand developed largely and became the center of economic and trade. Even it was chosen the capital of state because of the economic importance [12. Khorezm region also has a similar history: "Khorezm province has not gold and silver mines. All their wealth is left of Commerce. And Fennec, fox, sable and squirrel hair are brought to Khorezm from the Caspian [3]. The next feature of these cities was that the cost of traded goods was not high due to abundant transactions, while due to high traffic of roads the cities were flourished and safe.

In economically developed cities, after gathering in caravansaries, they traveled to other regions. Thus, for example, Nishapur is mentioned as the East Gate [13[, Nishapur has been on commercial routes [14] and "the wealth of merchants (of Nishapur) was enormous... it's silk and cotton fabrics were exported to other cities. The city textile and weaving is famous, taffeta and Rafeta garments are produced in this city, which are exported to other provinces [8]. Also, Samarkand is mentioned as the Gateway to China. In Ibn Haqul, ibid, 152) it is stated: "Samarkand ... is the world trade center ..." [15]. The caravanserais and traders were situated in suburbs, Samarkand was the Transoxiania commercial port and the best merchants grew in Samarkand [8]. Samarkand was the prelude of Transoxania and center of tradesmen where all the goods for commerce had arrived there and carried to other cities [16]. Also among the notes about Bukhara, it is stated "from it (Bukhara) good equipment and prayer carpets and furry are produced and taken to other places." [5] "...the market today is Friday Market and burlap and copper take from it to all provinces [4].

\subsubsection{Development of organized business with other areas}

the rise of productive jobs, followed by an increase in industrial and agricultural products in the cities of Khorasan paved the ground for the growth of professionalization in different fields of production. These issues, along with the economic situation of roads, provided the ground for development of organized trade with the rest of the world for exports of the region. This important issue was supported by rulers through building caravanserais in the skirts of cities and maintaining the security of cities and roads. [3, 4] In addition, the establishment of craftsmen was a sign of a civilization and of the main reasons was the development of cities in Khorasan while underlining the general welfare in cities and towns. With the presence of artisans, industry and the trade evolved. 
By diversifying business activities, the markets and commercial institutes also found variety. These guilds were distributed according to Islamic norms and regulations in the city, within a framework that prevents losses to the people [16]. Several examples of these groupings can be presented in different parts of Khorasan, such as: "There are places in Nishapur for professionals, such as hat makers, copper artisan, tent weavers, glass makers, goldsmith, shoe makers, retailers, rope makers, each were in their own markets". [3, 8, 17]. In the case of Bukhara and Marv [3] appears to be similar types of separation.

At this time because of the close relationship between trade and industry in the market, and creation of business guilds, official jobs for supervision on market and professional jobs emerged and public services developed in the context of laws and regulations that the government had developed. There were institutions that its constituent elements were related to the governor and his subordinates. In the next level, the control of public services was at the hands of security forces, such as the inspector or the sheriff. These were the organizations that run the cities and tried to solve its problems. These organizations administered the affairs based on Islamic rules and legislated rules for their development and promotion under the supervision of religious scholars.

\section{Conclusion}

Based on the above, it becomes clear that trade has a critical role in the development of Great Khorasan region during the early Islamic centuries. After the advent of Islam in Iran, including the Great Khorasan, because of the religious beliefs, the concept of the working class and the farmers changed. This led to the creation of productive jobs in cities. This should be considered the first reason of overpopulation of cities and their development.

With the diversity of crops and livestock production, it was necessary to export the surplus products to outside the region. The goods surplus was offered in the market of cities while most of these cities were located along the roads through which the people could communicate with other nations to establish trade and economic transactions, issue their goods and obtain the scarce materials required by the same way. That's why cities on the trade routes, for the sake of economic gravity had always drawn large crowds to the area and provided the ground for urban development.

Attention to the economic power of cities was so important that even cities such as Bukhara and Balkh, which had been destroyed with the arrival of Islam, revived once again because of economic importance in this period. There were also cities like Samarkand that because of trade-topographic importance had political significance and were chosen as the capital. The combination of these factors caused the population explosion in the region.

\section{References}

[1] Sahebi bazaz, M,(2014), PhD Thesis, Urban Khorasan and Transoxania from the ninth century to the eleventh century Tajik National University, Tehran Art University, p:136.

[2] Yousefi, Sh, (2010), The emergence of urbanism in Iran, Journal Iranian history, No. 64/5, p; 145-180.

[3] Estakhri, A, I, I (1989), Translated by Tostari, The effot Iraj Afshar, Tehran, Elmy Farhangi. P: 206-259. 
[4] Narshakhi Abu Bakr Muhammad ibn Ja'far, (1984), Tarekh Bukhara Translated by Muhammad ibn Zafar Ibn 'Umar, Correction Modares Razavi, Tehran, Tus, p:18-131.

[5] Hudud al-'Alam (1960), Unknown Author, The efforts of Manouchehr Sotoudeh, Tehran, University of Tehran,p:99-331.

[6] al-Muqaddas , M,(1982), Aḥsan al-taqāsim fī ma rifat al-aqālīm, Translated by Taqi Monzavi, Tehran,Shercat Moalefan va Motargeman Iran,p:323-476.

[7] Jihani, A, A, (2004), Ashkal al Alalam, Translated by Ali Abdul Salam Cutb, Mashhad, Beh Nashr,p; 186-187.

]8[ Ibn Hovqal, M, A, (1987), Șūrat al-'Arḍ, Translated by Jafar Shoar, Tehran, Amir Kabir, $\mathrm{p}: 216-217$.

]9[ al-Ya'qubi ,Ahmad ibn Abu Ya'qub ibn Ja'far ibn Wahb Ibn Wadih,(1963), Kitab alBuldan, Correction Muhammad Ibrahim Ayati, , Tehran, Bongah Targomh va nashr Ketab, p: 216.

]10[ Lestrange, G,(2011), Historical geography of the eastern lands of the Caliphate, Translated by Mahmoud Erfan, Tehran, Elmi Farhangi. P:9.

[11[ Bastani Parizi, M, E, (1987), Kerman, cities of Iran, , The efforts of Mohammad Yousuf Kiani, Tehran, SID. Volume 4,p: 233.

[12] Nasafi Azizuddin, M, (1955), Kashf Alhaqayq, Research by Ahmad Mohammadi Damghani, , Tehran, Bongah Targomh va nashr Ketab. P:208.

[13] al-Hamawi, Y, A, (1983), mu'jam al-buldān, , The efforts of Mohammad Parvin Gonabadi, Tehran, Amir Kabir,p: 223.

[14[ Ibn al-Faqih Hamadani، A, M, (1999), Mukhtasar Kitab al-Buldanar, Researcher Mohammad Reza Hakimi, Tehran,Farhang Iran,p: 87-167.

[15] Qazvini, Z. (1986), Monument of Places and History of God's Bondsmen, ,Translated by, Abdurrahman sharafkandi, , Tehran, Scientific Institute Andeshe Javan. Voh; 2, P: 225.

[16] Othman, M, S, (1997), Islamic Medina, Translated by Ali cheragi, Tehran, Amir Kabir. $\mathrm{P}: 82$.

[17] ibn Rasth, A, I,U, (1985), Alaq Alnfys•h, The efforts of Hussein Karachanlo, Tehran, Amir Kabi. P: 203. 